\title{
PERANAN DUKUNGAN SOSIAL PADA INTERAKSI POSITIF PEKERJAAN-KELUARGA DAN KEPUASAN HIDUP
}

\author{
Endang Dhamayantie \\ edhamayantie@yahoo.com \\ Fakultas Ekonomi Universitas Tanjungpura
}

\begin{abstract}
The objectives of this research is to examine and analyze the role of professional and personal social support on of both directions of positive interactions of work-family (work-family enrichment and family-work enrichment) and life satisfaction of employees on the work and family. The research was conducted on the employees from three public sector organizations in Pontianak, includes health service, finance and telecomunication sector. The data was collected from 120 employees. Samples were determined through purposive sampling method with sample criteria that worked in the public sector and are married. Methods of data collection by questionnaire. Data was analyzed using Structural Equation Modeling (SEM) with Partial Least Square (PLS). The results showed that 1) professional social support has significant positive effect on work-family enrichment; 2) personal social support has significant positive effect on family-work enrichment; 3) work-family enrichment has significant positive effect on job satisfaction; 4) work-family enrichment has significant positive effect on family satisfaction; 5) family-work enrichment has no significant effect on job satisfaction; and 6) family-work enrichment has significant positive effect on family satisfaction.
\end{abstract}

Keywords: Profesional Social Support, Personal Social Support, Work-Family Enrichment, Family-Work Enrichment, Job Satisfaction, Family Satisfaction.

\begin{abstract}
ABSTRAK
Tujuan penelitian ini adalah untuk menguji dan menganalisis peranan dukungan sosial profesional dan personal terhadap dua arah interaksi positif pekerjaan-keluarga (pengayaan pekerjaan-keluarga dan pengayaan keluarga-pekerjaan) serta kepuasan hidup karyawan pada pekerjaan dan keluarga. Penelitian dilakukan pada karyawan tetap dari tiga organisasi sektor publik di Kota Pontianak, mencakup sektor pelayanan kesehatan, keuangan dan telekomunikasi. Data dikumpulkan dari 120 karyawan. Sampel ditentukan melalui metode purposive sampling dengan kriteria sampel yang bekerja pada sektor publik dan sudah menikah. Metode pengumpulan data dengan kuesioner. Analisis data dilakukan dengan menggunakan Structural Equation Modeling (SEM) melalui pendekatan Partial Least Square (PLS). Hasil penelitian menunjukkan bahwa 1) dukungan sosial profesional berpengaruh positif signifikan terhadap pengayaan pekerjaan-keluarga; 2) dukungan sosial personal berpengaruh positif signifikan terhadap pengayaan keluarga-pekerjaan; 3) pengayaan pekerjaan-keluarga berpengaruh positif signifikan terhadap kepuasan kerja; 4) pengayaan pekerjaan-keluarga berpengaruh positif signifikan terhadap kepuasan keluarga; 5) pengayaan keluarga-pekerjaan berpengaruh positif tidak signifikan terhadap kepuasan kerja; dan 6) pengayaan keluarga-pekerjaan berpengaruh positif signifikan terhadap kepuasan keluarga.
\end{abstract}

Kata kunci: Dukungan Sosial Profesional, Dukungan Sosial Personal, Pengayaan Pekerjaan-Keluarga, Pengayaan Keluarga-Pekerjaan, Kepuasan Kerja, Kepuasan Keluarga.

\section{PENDAHULUAN}

Pekerjaan dan keluarga merupakan dua domain kehidupan yang berbeda namun saling berhubungan antara satu dengan yang lain. Artinya, kedua domain tersebut tidak dapat dipisahkan dan saling mempengaruhi, namun tuntutan pekerjaan seringkali bertentangan dengan tuntutan 
keluarga. Bahkan, seringkali pekerjaan didesain seolah-olah karyawan tidak mempunyai tanggung jawab keluarga (Bailyn et al., 2001) Hal ini menimbulkan konflik antar peran (Greenhaus dan Beutell, 1985). Hasilnya, sebagian besar studi-studi interaksi pekerjaan-keluarga memfokuskan pada pengaruh negatif interaksi kedua domain tersebut (Bhargava dan Baral, 2009; Brummelhuis dan Bakker, 2012; Chu, 2010; Grzywacz dan Marks, 2000; McNall et al., 2009; Stoddard dan Madsen, 2007).

Kritik muncul terhadap gagasan yang menyatakan bahwa peran pekerjaan dan keluarga selalu bersaing (Brummelhuis dan Bakker, 2012; Haar dan Bardoel, 2008; Greenhaus dan Powell, 2006), karena pada dasarnya kedua peran dapat saling memberikan manfaat dan berpengaruh positif. Pengaruh positif antar peran muncul ketika keterlibatan individu dalam berbagai peran dalam waktu yang bersamaan (misalnya peran dalam pekerjaan dan keluarga) saling memberikan manfaat yang mungkin dapat lebih besar dibandingkan biayanya (Wayne, 2009).

Manfaat yang diperoleh individu seperti keterampilan dan perilaku baru dalam domain pekerjaan atau pengalaman suasana hati positif dan peningkatan harga diri dalam domain keluarga ditransfer ke domain lainnya. Jika individu berhasil mengaplikasikan manfaat pada domain lainnya dan memungkinkan individu berfungsi lebih efektif dalam peran lainnya, maka dikatakan terjadi interaksi positif pekerjaankeluarga (Wayne, 2009). Aspek penting dalam perkembangan literatur sisi positif interaksi pekerjaan-keluarga adalah berbagai istilah yang digunakan peneliti untuk mengeksplorasi konsep tersebut, namun istilah yang banyak digunakan peneliti untuk menggambarkan interaksi positif pekerjaan-keluarga berdasarkan tinjauan 19 penelitian yang dilakukan Greenhaus dan Powell (2006) adalah pengayaan pekerjaankeluarga (work-family enrichment). Mirip dengan konsep konflik pekerjaan-keluarga, pengayaan memiliki sifat dua arah yaitu pengayaan pekerjaan-keluarga (work-family enrichment) dan pengayaan keluargapekerjaan (family-work enrichment) (Frone, 2003).

Perkembangan studi-studi tentang interaksi positif pekerjaan-keluarga tidak terlepas dari kerangka teoritis yang dipaparkan Sieber (1974) tentang teori akumulasi peran dan Marks (1977) melalui pendekatan ekspasionis. Teori akumilasi peran Sieber menjelaskan mengapa individu memilih untuk berpartisipasi dalam beragam peran. Menurut Sieber (1974), individu memperoleh beragam penghargaan dengan mengambil domain yang beragam, seperti keistimewaan peran yang lebih besar, ketegangan yang rendah dalam satu peran mengurangi pengaruh pada peran lain, peningkatan status yang lebih besar, dan pengayaan kepribadian (misalnya fleksibel, lebih toleransi terhadap ketidakcocokan) yang mengarah kepada kepuasan peran lebih besar dibandingkan stres. Sementara pendekatan ekspasionis dari Marks menyatakan bahwa beberapa peran memungkinkan menghasilkan pengaruh positif dalam bentuk meningkatnya energi pada peran lain. Keefektifan menangani beragam peran majemuk akan nampak terutama bagi individu yang memiliki sumberdaya yang lebih banyak atau mungkin lebih penting dan lebih tepat (Schultz, 2009). Hal ini berdasarkan pada pengalaman pengayaan yang tinggi pada satu peran akan dapat mengurangi konflik peran lainnya.

Mengelola interaksi positif pekerjaan dan keluarga secara simultan merupakan tantangan yang terus-menerus akan dihadapi organisasi dan individu yang bekerja dan memiliki tanggung jawab keluarga. Interaksi positif antara kehidupan pekerjaan dan keluarga menduduki posisi penting dalam kehidupan karyawan, organisasi, dan profesional sumberdaya manusia bilamana praktik-praktik sumberdaya manusia di tempat kerja ingin menciptakan lingkungan kerja yang positif dan produktif. Perhatian yang diberikan organi- 
sasi terhadap karyawan tentang manfaat mengkombinasikan peran pekerjaan dan keluarga akan membantu karyawan dalam mengelola tanggung jawab kedua domain (Stoddard dan Madsen, 2007), memungkinkan memberikan solusi bagi organisasi untuk menarik dan mempertahankan individu yang kapabel (Rashid et al., 2011), dan memberikan peningkatan outcome yang berhubungan dengan individu, keluarga dan organisasi (Bhargava dan Baral, 2009; McNall et al., 2009). Untuk itu, pendekatan holistik diperlukan untuk menghadapi tantangan dalam menyatukan kehidupan pekerjaan dan keluarga agar dapat memberikan hasil yang lebih produktif (Bailyn et al., 2001).

Berdasarkan tipologi Allen et al. (2000), konsekuensi dari interaksi pekerjaankeluarga mencakup kategori yang berkaitan dengan pekerjaan (kepuasan kerja, komitmen afektif, keinginan berpindah kerja), kategori yang berkaitan dengan bukan pekerjaan (kepuasan keluarga dan kepuasan hidup) dan kategori yang berkaitan dengan kesehatan (kesehatan fisik dan mental). Hasil investigasi analisis meta yang dilakukan McNall et al. (2009) terhadap 21 studi pengayaan pekerjaan-keluarga dan 25 studi pengayaan keluarga-pekerjaan, baik yang dipublikasikan maupun tidak, menunjukkan bahwa konsekuensi pengayaan pekerjaan-keluarga dan keluarga pekerjaan mencakup aspek-aspek yang berhubungan dengan pekerjaan (kepuasan kerja, komitmen afektif, keinginan berpindah pekerjaan), yang tidak berhubungan dengan pekerjaan (kepuasan keluarga, kepuasan hidup) dan kesehatan (fisik, mental). Penelitian lainnya menunjukkan konsekuensi dari interaksi positif pekerjaan-keluarga seperti kinerja, kepuasan kerja, kepuasan keluarga, kepuasan hidup, komitmen afektif, dan perilaku sosial organisasi (Bhargava dan Baral, 2009; Carlson et al., 2010; Hasan et al., 2009).

Implikasi bagi individu dan organisasi adalah berusaha memfokuskan pada caracara untuk meningkatkan interaksi positif pekerjaan-keluarga sebagai alternatif mengurangi dampak negatif dari konflik pekerjaan-keluarga (McNall et al., 2009; Warner dan Hausdorf, 2009). Untuk pengembangan karir dan keseimbangan dalam hubungan keluarga beberapa aspek sumberdaya yang diperlukan antara lain dukungan sosial profesional dan personal (Ezzedeen dan Ritchey, 2009). Dukungan sosial profesional diperoleh dari atasan, mentor, rekan kerja, dan orang lain yang ada dalam domain pekerjaan, sementara dukungan sosial personal diperoleh dari lingkungan keluarga seperti pasangan (sua$\mathrm{mi}$ /istri), anak-anak, orang tua/mertua, dan teman-teman. Dukungan sosial profesional dan personal diperlukan mengingat tuntutan dunia kerja yang semakin berat dan kebutuhan anggota keluarga akan perhatian. Dalam domain pekerjaan, berbagai tekanan terjadi seperti jam kerja, jadwal kerja yang tidak fleksibel, konflik peran, ambiguitas peran, kegiatan yang membatasi gerak, dan harapan dari atasan (Greenhaus dan Beutell, 1985). Dalam domain keluarga, tekanan dapat ditimbulkan dari anak-anak yang masih kecil, pekerjaan suami/istri, keluarga besar, kurangnya dukungan pasangan, pertengkaran dalam keluarga, dan harapan anggota keluarga akan kehangatan dan sifat terbuka (Higgins dan Duxbury, 1992).

Pentingya pengkajian peranan dukungan sosial terhadap interaksi positif pekerjaan-keluarga dan kepuasan hidup juga tidak terlepas dari kondisi riil yang nampak. Peningkatan jumlah wanita dalam angkatan kerja di Indonesia $(43,5 \%$ dari seluruh angkatan kerja), peningkatan jumlah pasangan karir ganda (dual-career family) dimana suami dan istri memiliki pekerjaan dan tanggung jawab keluarga sehingga mayoritas anak-anak tumbuh dengan kedua orang tua yang bekerja di luar rumah (Mondy, 2008) dan meningkatnya jumlah rumah tangga perorang tua tunggal akibat perceraian (hingga 2010, angka perceraian di Indonesia meningkat 70\%), merupakan tantangan dan peluang bagi organisasi 
untuk peka dan lebih fleksibel terhadap kebutuhan individu.

Dukungan sosial merupakan sumberdaya yang penting dalam memperkaya hubungan peran pekerjaan dan keluarga, namun penelitian-penelitian tentang interaksi positif pekerjaan-keluarga sebelumnya belum banyak mengeksplorasi peranan tersebut. Hasil-hasil penelitian sebelumnya lebih banyak mengeksplorasi anteseden interaksi positif pekerjaan-keluarga seperti karakteristik personal (pendidikan, pendapatan, gender, ras) dan stres (stres pe kerjaan, stres keluarga), serta keterlibatan psikologis di tempat kerja dan rumah (Grzywacz dan Marks, 2000; Washington, 2006). Terbatasnya hasil-hasil penelitian empiris yang menguji pengaruh dukungan sosial dengan interaksi positif pekerjaankeluarga dan kepuasan hidup, memungkinkan untuk mengkaji lebih lanjut peranan dukungan sosial yang secara logis membantu karyawan mengelola peran dalam domain pekerjaan dan keluarga. Selain itu, dukungan sosial telah digunakan sebagai anteseden dalam penelitian interaksi negatif pekerjaan-keluarga (MdSidin et al., 2010; Namayandeh et al., 2010; Ryan et al., 2001), sehingga dukungan sosial yang dapat memberikan bantuan instrumental untuk membantu karyawan mengubah tuntutan pekerjaan dan keluarga yang saling bersaing menjadi saling memberikan manfaat, memungkinkan juga untuk digunakan dalam penelitian interaksi positif pekerjaankeluarga. Penelitian Bhargava dan Baral (2009) menunjukkan dukungan sosial krusial untuk pengayaan pekerjaan-keluarga.

Objek penelitian berfokus pada karyawan tetap yang telah menikah dan bekerja pada sektor publik di Kota Pontianak yang banyak terlibat dalam pemenuhan kebutuhan dan pelayanan kepada masyarakat. Sektor publik di Kota Pontianak telah menjadi bagian penting dari setiap upaya reformasi birokrasi dalam menyajikan pelayanan bagi pemenuhan kebutuhan serta akomodasi berbagai kepentingan dan kesejahteraan masyarakat. Oleh karena itu, untuk memenuhi tuntutan tersebut, dukungan sosial diperlukan karyawan sebagai satu fungsi ikatan sosial untuk mengurangi beban atau permasalahan yang dihadapi karyawan sektor publik dalam domain pekerjaan dan keluarga sehingga menghasilkan pekerjaan yang berkualitas.

Berdasarkan uraian di atas, tujuan dari penelitian ini adalah untuk menguji pengaruh dukungan sosial terhadap interaksi positif pekerjaan-keluarga dan kepuasan hidup pada karyawan sektor publik di Kota Pontianak. Pengujian ini relevan untuk dilakukan mengingat masalah yang dihadapi karyawan sektor publik terkait dengan sifat pekerjaan yang dimiliki karyawan di sektor publik seperti beban kerja berlebihan dan tekanan waktu ditempat kerja seperti banyaknya pekerjaan yang harus diselesaikan, disamping tuntutan keluarga yang harus dipenuhi.

\section{TINJAUAN TEORETIS Dukungan Sosial}

Dukungan sosial menggambarkan hubungan individu dengan lingkungan sosialnya. Hubungan ini melibatkan berbagai aspek dukungan yang diterima individu atau komunitas sosial dari orang lain dan lingkungan sosial yang lebih luas. Dukungan sosial menurut Gotlieb (1983) merupakan informasi verbal atau non verbal, saran, bantuan nyata atau tingkah laku yang diberikan orang-orang yang dekat dengan subjek di dalam lingkungan sosialnya atau berupa kehadiran dan hal-hal yang memberikan keuntungan emosional atau berpengaruh pada tingkah laku penerimanya. Dengan adanya dukungan sosial ini seseorang akan merasa mudah dalam menjalankan peran yang beragam.

Sarafino (1990) membagi dukungan sosial dalam lima macam antara lain dukungan instrumental, informasional, emosional, harga diri dan kelompok sosial. Dukungan instrumental merupakan bentuk dukungan berupa penyediaan materi seperti pinjaman uang, pemberian barang, makanan serta pelayanan. Dukungan 
informasional merupakan bentuk dukungan yang mencakup pemberian informasi, saran atau umpan balik tentang situasi dan kondisi individu. Dukungan emosional adalah bentuk dukungan yang membuat individu memiliki perasaan nyaman, yakin, diperdulikan dan dicintai oleh sumber dukungan sosial sehingga individu dapat menghadapi masalah dengan lebih baik. Dukungan pada harga diri adalah bentuk dukungan berupa penghargaan positif pada individu, pemberian semangat, persetujuan pada pendapat individu, perbandingan yang positif dengan individu lain. Dukungan dari kelompok sosial adalah bentuk dukungan yang akan membuat individu merasa sebagai anggota dari suatu kelompok yang memiliki kesamaan minat dan aktifitas sosial dengannya.

Berdasarkan sumbernya, dukungan sosial dibagi menjadi dua kategori yaitu dukungan sosial dari domain pekerjaan (dukungan sosial profesional) dan dukungan sosial dari domain keluarga (dukungan sosial personal). Dukungan sosial profesional dapat diperoleh dari supervisor, mentor, rekan kerja dan pihak lain yang berhubungan dengan pekerjaan, sementara dukungan sosial personal diperoleh dari pasangan (suami/istri), orang tua, anakanak dan teman-teman (Ezzedeen dan Ritchey, 2009). Dukungan sosial profesional dapat mengurangi beban yang diterima dalam pekerjaan, sedangkan dukungan sosial personal mengurangi beban dalam peran keluarga.

\section{Interaksi Positif Pekerjaan-Keluarga}

Dasar yang dapat digunakan untuk menjelaskan interaksi positif pekerjaankeluarga adalah teori pertukaran sosial yang dikemukakan Blau (1964). Teori pertukaran sosial menekankan tindakan sukarela individu yang dimotivasi oleh hasil yang diharapkan dari orang lain. Tiga poin utama dari teori tersebut adalah tindakan sukarela, hasil yang diharapkan, dan hasil yang diperoleh dari pihak lain. Misalnya, karyawan yang membantu rekannya yang menghadapi beban kerja yang berlebih berharap rekannya akan melakukan hal yang sama untuk dirinya (Zhang et al., 2011). Aplikasi teori ini dalam interaksi pekerjaan-keluarga adalah bila karyawan merasakan organisasi mereka membantu mereka mengelola peran pekerjaan dan keluarga, mereka kemungkinan merasa didukung dan diperhatikan oleh organisasi (McNall et al., 2009), seperti perasaan positif terhadap pekerjaan dan organisasi.

Gagasan bahwa kehidupan pekerjaan dan keluarga dapat saling memberikan manfaat diperkenalkan Sieber (1974) dan Marks (1977). Menurut Wayne (2009), keduanya pertama kali menantang hipotesis "kelangkaan sumberdaya" dan berpendapat bahwa keterlibatan dalam beragam peran memberikan manfaat yang mungkin dapat lebih besar dibandingkan biayanya serta memberikan dasar teori pengaruh positif beragam peran yang memperluas lensa interaksi pekerjaan-keluarga dari perspektif konflik.

Sieber melalui teori peningkatan peran menjelaskan bahwa beragam peran dapat dihubungkan dengan berbagai penghargaan seperti keistimewaan peran, keamanan status, sumberdaya, pengayaan pribadi, dan kepuasan diri. Dengan kata lain keterlibatan dalam beragam peran dapat meningkatkan fungsi dalam peran lain lebih baik (Washington, 2006).

Marks (1977) kemudian mengembangkan teori ekspansi dalam merespon hipotesis kelangkaan. Marks memandang energi manusia sebagai fenomena supply-demand dan berpendapat bahwa ketika individu menggunakan energi untuk menampilkan beragam peran, tubuh akan menghasilkan energi untuk menampilkan peran lain. Marks menegaskan bahwa ketegangan peran tidak disebabkan oleh pertentangan tuntutan peran yang berbeda tetapi oleh ketidakseimbangan peran, dimana terdapat perbedaan kepentingan antara peran yang dijalankan, dan ketegangan peran tidak akan terjadi bila semua komitmen memiliki nilai-nilai positif atau negatif yang sama. 
Karena norma-norma dan peran budaya dalam keluarga dan organisasi berubah secara dramatis, peningkatan perhatian terhadap teori ekspansi telah membawa para peneliti untuk berpikir ulang tentang hubungan positif antara peran pekerjaan dan keluarga (Zhang et al., 2011).

Selanjutnya Crouter (1984) mengungkapkan teori limpahan positif, teori ini mengenalkan potensi-potensi limpahan positif interaksi pekerjaan-keluarga dan sebaliknya berupa dukungan kehidupan keluarga, fasilitasi, dan meningkatkan kehidupan kerja. Berbeda dengan konflik pekerjaan-keluarga, pengayaan pekerjaankeluarga merujuk pada sejauh mana pengalaman dalam satu peran meningkatkan kualitas hidup dalam peran lain (Greenhaus dan Powell, 2006). Greenhaus dan Powell (2006) menyatakan bahwa istilah pengayaan sinonim dengan peningkatan, limpahan positif, dan fasilitasi. Persamaannya adalah masing-masing konstruk menggambarkan saling mempengaruhi secara positif antara pekerjaan dan keluarga. Sama halnya dengan konflik pekerjaan-keluarga, pengayaan mempunyai sifat dua arah. Artinya, manfaat yang diperoleh dari pekerjaan dan diaplikasikan pada keluarga (pengayaan pekerjaan terhadap keluarga) atau diperoleh dari keluarga dan diaplikasikan pada pekerjaan (pengayaan keluarga terhadap pekerjaan).

Carlson et al. (2006) mengembangkan dan memvalidasi skala untuk mengukur pengayaan pekerjaan-keluarga dan keluarga-pekerjaan. Arah pekerjaan terhadap keluarga mencakup pengembangan, afek dan modal. Pengembangan terjadi bila keterlibatan dalam pekerjaan membawa pada perolehan atau perbaikan keterampilan, pengetahuan, perilaku, atau cara memandang sesuatu yang membantu individu menjadi anggota keluarga lebih baik. Afek didefinisikan bila keterlibatan dalam pekerjaan menghasilkan keadaan emosional positif atau sikap yang membantu individu menjadi anggota keluarga lebih baik. Modal terjadi bila keterlibatan dalam pekerjaan menghasilkan tingkat sumberdaya psikososial seperti rasa aman, keyakinan, prestasi, atau pemenuhan diri yang membantu individu menjadi anggota keluarga lebih baik. Sementara arah keluarga terhadap pekerjaan mencakup pengembangan, afek dan efisiensi. Pengembangan terjadi bila keterlibatan dalam keluarga membawa pada perolehan atau perbaikan keterampilan, pengetahuan, perilaku atau cara memandang sesuatu yang membantu individu menjadi karyawan lebih baik. Afek terjadi bila keterlibatan dalam keluarga menghasilkan keadaan emosional positif atau sikap yang membantu individu menjadi karyawan lebih baik. Efisiensi terjadi bila keterlibatan dalam keluarga memberikan perasaan fokus atau perasaan urgensi yang membantu individu menjadi karyawan lebih baik.

Meskipun riset-riset telah banyak mendemostrasikan bahwa kehidupan pekerjaan dan keluarga mempunyai kapabilitas untuk memperkaya peran lain, masih sedikit risetriset empirik yang didesain untuk memahami seluk beluk proses pengayaan (Schultz, 2009).

\section{Kepuasan Hidup}

Dalam kehidupan organisasi modern, kepuasan hidup karyawan dijadikan ukuran tingkat kematangan organisasi, dan tanda bahwa organisasi dikelola dengan baik. Oleh karena itu, organisasi melalui departemen sumber daya manusia harus senantiasa memonitor kepuasan karyawan sebagai upaya antisipasi dampak negatif terhadap kepuasan yang rendah. Kepuasan hidup dibagi menjadi tiga bagian yaitu kepuasan kerja, kepuasan keluarga dan kepuasan kesejahteraan (Rashid et al. 2011). Dalam penelitian ini kepuasan hidup yang digunakan yaitu kepuasan kerja dan kepuasan keluarga.

Schermerhorn (2002) menjelaskan bahwa kepuasan kerja merupakan sebuah sikap yang penting dan dapat mempengaruhi perilaku di tempat kerja. Robbins (2003) mendeskripsikan kepuasan kerja yang 
merujuk ke sikap umum seseorang individu terhadap pekerjaannya yang menunjukkan kalau seseorang dengan tingkat kepuasan yang tinggi akan memperlihatkan sikap positif terhadap pekerjaannya, sebaliknya seseorang yang tidak puas dengan pekerjaannya menunjukkan sikap yang negatif terhadap perkerjaan. Sementara Luthans (2005) mendefinisikan kepuasan kerja adalah sikap yang dimiliki karyawan mengenai pekerjaannya. Kepuasan kerja menunjukkan sikap pribadi seseorang sehingga kepuasan dan ketidakpuasan yang dirasakan tiap-tiap karyawan jelas berbeda.

Luthans (2005) membagi kepuasan kerja menjadi tiga dimensi. Pertama, kepuasan kerja adalah suatu emosi yang merupakan respon terhadap situasi kerja. Hal ini tidak dapat dilihat tetapi hanya dapat dirasakan dan akan tercermin dalam sikap karyawan. Kedua, kepuasan kerja dinyatakan dengan hasil yang sesuai atau bahkan melebihi yang diharapkan. Ketiga, kepuasan kerja biasanya dinyatakan dalam sikap, misalnya semakin loyal pada perusahaan, bekerja dengan baik, berdedikasi tinggi pada perusahaan, tertib dan mematuhi peraturan serta sikap-sikap lain yang bersifat positif. Kepuasan keluarga merujuk pada reaksi afektif terhadap keluarga, yang merefleksikan sejauh mana individu mempunyai perasaan positif tentang situasi keluarga mereka. Dengan kata lain, kepuasan keluarga merupakan keadaan emosional yang menyenangkan (positif) yang berasal dari penilaian seseorang sebagai anggota keluarga. Seseorang yang mempunyai sikap positif terhadap keluarga nya berarti mempunyai kepuasan keluarga yang tinggi, sebaliknya seseorang yang mempunyai sikap negatif terhadap keluarganya, berarti mempunyai tingkat kepuasan keluarga yang rendah (Frone et al., 1992).

\section{Hubungan Dukungan Sosial dengan Interaksi Positif Pekerjaan-Keluarga}

Powell dan Greenhaus (2006) memberikan sebuah model untuk memahami bagai- mana proses satu peran dapat memperkaya peran yang lain. Dalam modelnya, Powell dan Greenhaus (2006) menyatakan salah satu sumberdaya yang dapat dihasilkan dalam satu peran yang mempengaruhi kualitas kehidupan dalam peran yang lain adalah sumberdaya modal sosial.

Dukungan sosial profesional diperoleh dari supervisor, mentor, rekan kerja dan pihak lain yang berhubungan dengan pekerjaan. Dukungan supervisor atau mentor menggambarkan persepsi karyawan apakah supervisor atau mentor sensitif terhadap masalah-masalah yang berhubungan dengan pekerjaan. Dukungan supervisor krusial untuk pengayaan pekerjaan-keluarga karena supervisor dapat mengurangi beban dan ketegangan dalam pekerjaan. Hal ini juga didukung oleh penelitian Bhargava dan Baral (2009) yang menunjukkan bahwa dukungan supervisor merupakan prediktor pengayaan pekerjaan-keluarga dan keluarga-pekerjaan.

Dukungan dari rekan kerja diperoleh di tempat kerja dari interaksi dengan semua karyawan. Menurut Mustafa et al. (2012), rekan kerja mempunyai peluang yang unik untuk memberikan dukungan karena mereka mempunyai pemahaman yang jelas tentang sifat tekanan yang dihadapi rekan kerjanya. Rekan kerja menawarkan bantuan emosional dan instrumental terhadap karyawan untuk menyeimbangkan peran pekerjaan dan keluarga. Rekan kerja memiliki posisi optimal untuk menawarkan dukungan bagi karyawan untuk menghadapi konflik pekerjaan-keluarga karena mereka memiliki pengetahuan pertama tentang tekanan yang berhubungan dengan tempat kerja. Meskipun mayoritas penelitian dukungan rekan kerja mengurangi konflik pekerjaan-keluarga, rekan kerja juga dimungkinkan memberikan bantuan instrumental untuk membantu karyawan mengubah tuntutan pekerjaan dan keluarga yang saling bersaing. Dalam menyelesaikan pekerjaan misalnya, dukungan rekan kerja memfasilitasi keluarga mencakup menutupi atau menukar tugas-tugas pekerjaan atau 
shift kerja, memberikan material atau informasi yang hilang terhadap rekan kerja karena masalah keluarga, atau mendukung rekan kerja meninggalkan pekerjaan untuk merawat anak sakit (Mesmer-Magnus dan Viswesvaran, 2008).

Dukungan sosial personal yang diperoleh dari keluarga seperti pasangan (suami/istri), orang tua, anak-anak dan teman-teman. Dukungan keluarga diakui sebagai salah satu sumberdaya yang dapat meningkatkan peran pekerjaan dan keluarga, terlebih dalam budaya kolektif. Lu et al. (2009) menguji proposisi dan menemukan bahwa dukungan sosial diasosiasikan dengan pengayaan pekerjaan-keluarga.

Kesadaran akan pentingnya karyawan dalam organisasi dan keinginan karyawan untuk mencapai kualitas kehidupan yang lebih baik telah mengarahkan subjek penelitian pada interaksi positif pekerjaankeluarga. Beberapa waktu terakhir, penelitian tentang interaksi positif antara domain pekerjaan dan keluarga mengalami perkembangan. Namun, masih sedikitnya ekspansi yang dilakukan peneliti mengenai anteseden interaksi positif pekerjaankeluarga, mendorong peneliti mengintegrasikan salah satu model yang di- rancang Powell dan Greenhaus yaitu sumberdaya dukungan sosial sebagai sebuah penjelasan mengenai pengayaan pekerjaan-keluarga dan keluarga-pekerjaan dan dampaknya terhadap kepuasan hidup. Frone (2003) memandang dukungan sosial merupakan anteseden terpenting dari pengayaan pekerjaan-keluarga.

\section{Hubungan Interaksi Positif Pekerjaan- Keluarga dengan Kepuasan Hidup}

Teori akumulasi peran Sieber menjadi dasar untuk menjelaskan manfaat akumulasi peran yang lebih besar dan menghasilkan kepuasan hidup (Haar dan Bardoel, 2008). Penelitian McNall et al. (2009) dan McNall et al. (2010) menemukan bahwa interaksi positif pekerjaan-keluarga baik pengayaan pekerjaan-keluarga dan keluarga-pekerjaan berhubungan dengan kepuasan kerja.

Beberapa penelitian juga membuktikan bahwa peningkatan limpahan positif akan mempengaruhi kepuasan keluarga lebih besar (Edwards dan Rothbard, 2000; Haar dan Bardoel, 2000). Selain itu, tingginya limpahan positif berhubungan dengan rendahnya konflik perkawinan (Grzywacz dan Marks, 2000).

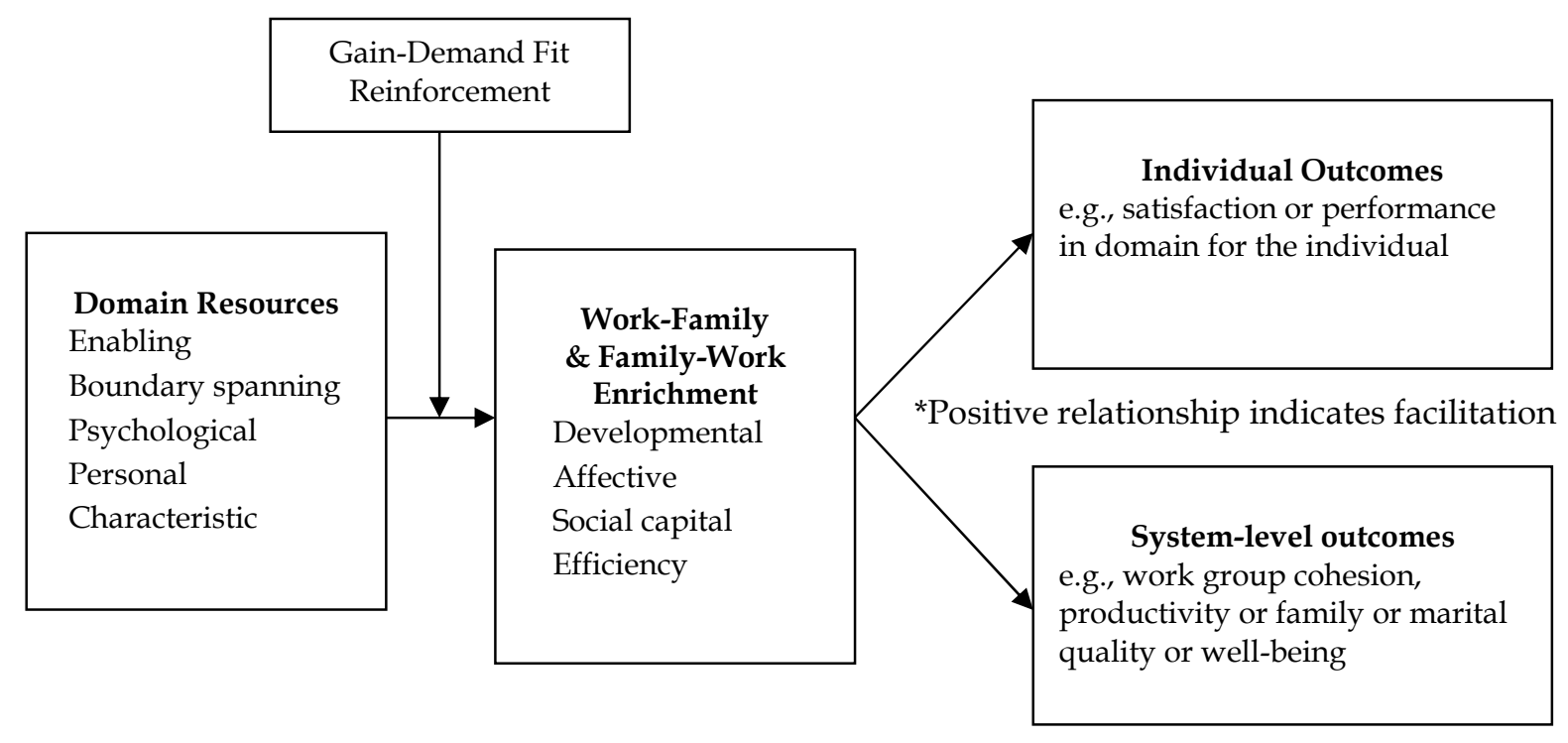

Gambar 1

Anteseden, Moderator dan Konsekuensi Utama Pengayaan Pekerjaan-Keluarga Sumber: Wayne (2009). 
Dukungan terhadap dua arah limpahan positif pekerjaan-keluarga dan keluargapekerjaan berhubungan positif dengan kepuasan keluarga (Haar dan Bardoel, 2008). Bhargava dan Baral (2009) juga telah membuktikan dampak pengayaan pekerjaankeluarga terhadap kepuasan kerja sedangkan dampak pengayaan keluarga-pekerjaan adalah kepuasan kerja dan kepuasan keluarga. Sementara penelitian Hasan et al. (2009) mendukung pengayaan pekerjaankeluarga berhubungan positif dengan kepuasan kerja sedangkan pengayaan keluarga-pekerjaan berhubungan positif dengan kepuasan keluarga. Analisis meta McNall et al. (2009) juga menunjukkan bahwa baik pengayaan pekerjaan-keluarga dan keluarga pekerjaan berdampak terhadap kepuasan kerja, kepuasan keluarga dan kepuasan hidup. Demikian juga penelitian Carlson et al. (2010) yang telah membuktikan bahwa kepuasan kerja dan kepuasan keluarga merupakan konsekuensi yang didapat dari interaksi positif pekerjaan-keluarga. Wayne (2009) membangun sebuah model umum yang lebih komprehensif yang menggambarkan anteseden, moderator dan konsekuensi dari pengayaan pekerjaankeluarga seperti yang ditunjukkan pada Gambar 1.

Berdasarkan kajian teoritis dan hasilhasil empiris yang menunjukkan hubungan antar variabel serta kerangka konseptual dasar Wayne pada Gambar 1, maka dikembangkan rerangka konseptual penelitian seperti ditunjukkan pada Gambar 2 dan hipotesis penelitian sebagai berikut:

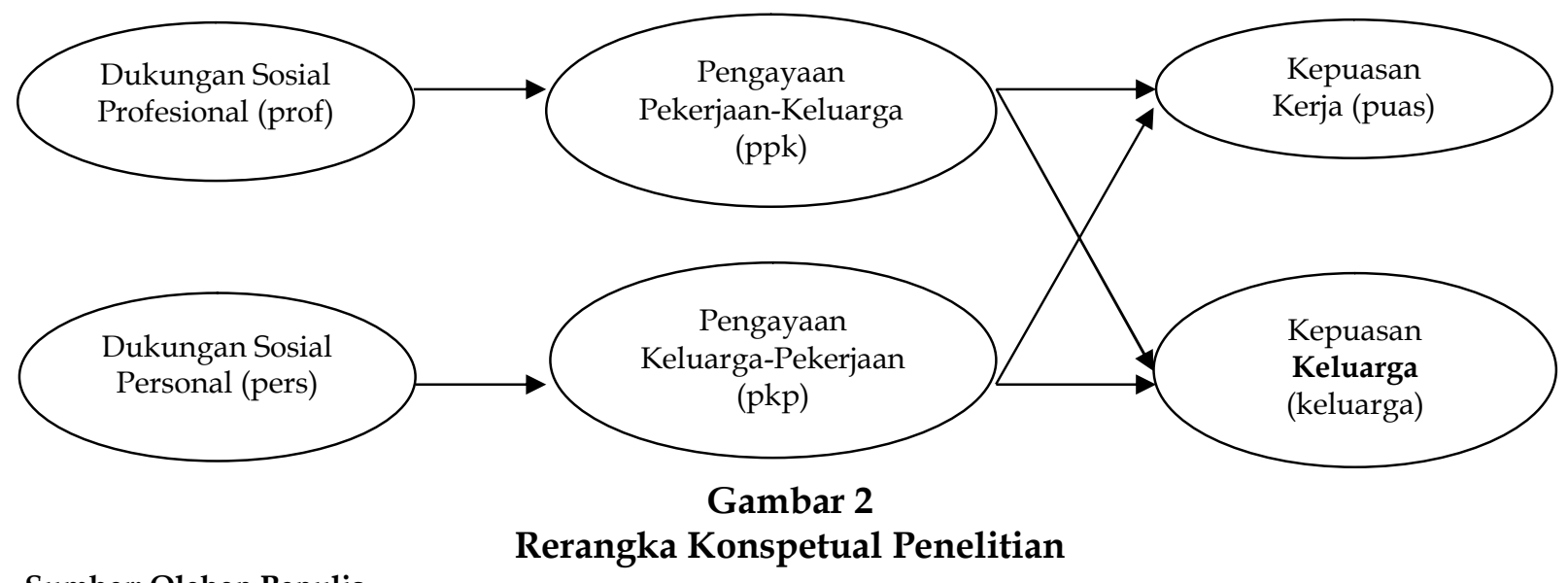

Sumber: Olahan Penulis

$\mathrm{H}_{1}$ : Dukungan sosial professional berpengaruh positif signifikan terhadap pengayaan pekerjaan-keluarga.

$\mathrm{H}_{2}$ : Dukungan sosial personal berpengaruh positif signifikan terhadap pengayaan keluarga-pekerjaan.

$\mathrm{H}_{3}$ : Pengayaan pekerjaan-keluarga berpengaruh positif signifikan terhadap kepuasan kerja.

$\mathrm{H}_{4}$ : Pengayaan pekerjaan-keluarga berpengaruh positif signifikan terhadap kepuasan keluarga.

$\mathrm{H}_{5}$ : Pengayaan keluarga-pekerjaan berpengaruh positif signifikan terhadap kepuasan kerja.
$\mathrm{H}_{6}$ : Pengayaan keluarga-pekerjaan berpengaruh positif signifikan terhadap kepuasan keluarga.

\section{METODE PENELITIAN \\ Jenis Penelitian}

Penelitian ini merupakan jenis penelitian penjelasan (explanatory research). Explanatory research bertujuan untuk menjelaskan pengaruh dan hubungan antar variabel penelitian dan menguji hipotesis yang telah dirumuskan terlebih dahulu (Singarimbun, 1995). 


\section{Populasi, Sampel dan Teknik Pengambil- an Sampel}

Populasi dalam penelitian ini adalah seluruh karyawan tetap yang sudah menikah pada sektor publik di Kota Pontianak antara lain sektor pelayanan kesehatan, keuangan dan telekomunikasi. Penarikan sampel sejumlah 120 karyawan. Pengambilan sampel menggunakan teknik purposive sampling dengan kriteria 1) bekerja pada sektor publik; dan 2) sudah menikah. Response rate dari hasil kuesioner yang disebar sebesar $97 \%$.

\section{Definisi Operasional Variabel}

Variabel dalam penelitian ini meliputi variabel eksogen yaitu dukungan sosial profesional (prof) dan dukungan sosial personal (pers), variabel intervening yaitu pengayaan pekerjaan-keluarga (ppk) dan pengayaan keluarga-pekerjaan (pkp), serta variabel endogen yaitu kepuasan kerja (puas) dan kepuasan keluarga (keluarga).

\section{Dukungan sosial profesional (prof)}

Dukungan sosial profesional adalah suatu transaksi interpersonal dalam pekerjaan yang melibatkan bantuan dalam bentuk dukungan instrumen yang diterima individu sebagai anggota jaringan sosial. Instrumen pengukuran dukungan sosial profesional diukur dengan menggunakan indikator: bantuan dari atasan/rekan kerja, saran atau umpan balik dari atasan/rekan kerja, kepedulian atasan/rekan kerja, penghargaan positif dari atasan/rekan kerja, dan dukungan atasan/rekan kerja dalam pekerjaan.

\section{Dukungan sosial personal (pers)}

Dukungan sosial personal adalah suatu transaksi interpersonal dalam keluarga yang melibatkan bantuan dalam bentuk dukungan instrumen yang diterima individu sebagai anggota jaringan sosial. Instrumen pengukuran dukungan sosial personal diukur dengan menggunakan indikator: bantuan dari orang tua/pasangan/anakanak/teman, saran atau umpan balik dari orang tua/pasangan/anak-anak/teman, kepedulian orang tua/pasangan/anak-anak/ teman, penghargaan positif dari orang tua/ pasangan/anak-anak/teman, dan dukungan orang tua/pasangan/anak-anak/teman dalam pekerjaan.

\section{Pengayaan pekerjaan-keluarga (ppk)}

Pengayaan pekerjaan-keluarga menunjukkan sejauh mana pengalaman dalam pekerjaan dapat meningkatkan kualitas kehidupan keluarga. Pengayaan pekerjaankeluarga diukur dengan item-item yang diadaptasi dari Carlson et al. (2006), yaitu: pengembangan; terjadi bila keterlibatan dalam pekerjaan membawa pada perolehan atau perbaikan keterampilan, pengetahuan, perilaku atau cara memandang sesuatu yang membantu individu menjadi anggota keluarga lebih baik, afek; terjadi bila keterlibatan dalam pekerjaan menghasilkan keadaan emosional positif atau sikap yang membantu individu menjadi anggota keluarga lebih baik, dan modal; terjadi bila keterlibatan dalam pekerjaan menghasilkan tingkat sumberdaya seperti rasa aman, keyakinan, prestasi atau pemenuhan diri yang membantu individu menjadi anggota keluarga lebih baik.

\section{Pengayaan keluarga-pekerjaan (pkp)}

Pengayaan keluarga-pekerjaan menunjukkan sejauh mana pengalaman dalam peran keluarga dapat meningkatkan kualitas kehidupan pekerjaan. Pengayaan keluarga-pekerjaan diukur melalui item-item dari Carlson et al. (2006) antara lain: pengembangan; terjadi bila keterlibatan dalam keluarga membawa pada perolehan atau perbaikan keterampilan, pengetahuan, perilaku atau cara memandang sesuatu yang membantu individu menjadi karyawan lebih baik, afek; terjadi bila keterlibatan dalam keluarga menghasilkan keadaan emosional positif atau sikap yang membantu individu menjadi karyawan lebih baik, dan efisiensi; terjadi bila keterlibatan dalam keluarga memberikan perasaan fokus 
atau perasaan urgensi yang membantu individu menjadi karyawan lebih baik.

\section{Kepuasan kerja (puas)}

Kepuasan kerja adalah keadaan emosional menyenangkan maupun tidak menyenangkan terhadap pekerjaan. Kepuasan kerja diukur dengan item-item dari Job Description Index meliputi: puas dengan pekerjaan, puas dengan gaji, puas dengan promosi, puas dengan supervisor, dan puas dengan teman sekerja.

\section{Kepuasan Keluarga (keluarga)}

Kepuasan Keluarga adalah keadaan emosional individu terhadap kehidupan keluarga. Kepuasan keluarga diukur dengan menggunakan item-item dari Hackman dan Oldham (1975) yang terdiri dari kepuasan terhadap peran dalam keluarga dan kepuasan dengan kehidupan keluarga.

Semua item-item penelitian diukur dengan menggunakan skala Likert dengan skala 1 (sangat tidak setuju) sampai 5 (sangat setuju).

\section{Uji Validitas dan Reliabilitas Instrumen Penelitian}

Instrumen pengumpulan data dalam penelitian ini adalah kuesioner. Kuesioner berisi sejumlah pernyataan dari indikatorindikator variabel penelitian. Sebelum seluruh kuesioner disampaikan kepada responden, terlebih dahulu dilakukan uji coba kuesioner terhadap 30 orang responden. Tujuannya adalah untuk mengetahui apakah alat ukur yang digunakan dalam kuesioner memiliki validitas dan reliabilitas pengukuran. Pengujian validitas menggunakan Pearson's Product Moment Corelation, sementara pengujian reliabilitas dilakukan dengan menggunakan Cronbach's alpha. Hasil uji validitas dan reliabilitas menunjukkan semua item valid dan semua variabel reliabel.

\section{Teknik Analisis}

Model analisis yang digunakan dalam penelitian ini melalui Structural Equation
Modeling (SEM) melalui pendekatan partial least square (PLS). PLS adalah structural equation modeling (SEM) berbasis component atau variance (Ghozali, 2008). Kegunaan PLS adalah untuk mendapatkan model struktural yang powerfull guna tujuan prediksi (Solimun, 2011) dan tidak mengasumsikan data harus dengan pengukuran skala tertentu serta jumlah sampel kecil dan menguji keseluruhan kesesuaian model (overall model fit) dengan baik (Ghozali, 2008).

\section{ANALISIS DAN PEMBAHASAN}

Penelitian dilakukan pada karyawan yang sudah menikah dan bekerja di sektor publik. Dari 120 kuesioner yang disebarkan, sebanyak 116 kuesioner kembali dan dapat diolah lebih lanjut (response rate sebesar 97\%). Deskripsi responden penelitian menunjukkan jenis kelamin responden hampir seimbang (pria 48\%, wanita 52\%). Pada dasarnya pria dan wanita mempunyai harapan peran kerja, dukungan sosial profesional dan personal, tingkat interaksi positif pekerjaan-keluarga, dan kepuasan hidup yang sama. Namun, beberapa literatur interaksi pekerjaan-keluarga menunjukkan hipotesis gender yang berbeda. Umur responden sebagian besar berada pada rentang 31-40 tahun sebanyak $46 \%$. Rentang umur tersebut menunjukkan responden berada pada umur produktif. Mayoritas pendidikan responden adalah Sarjana. Semakin tinggi tingkat pendidikan diharapkan berkorelasi dengan kemampuan responden untuk dapat mengimplementasikan interaksi positif pekerjaan-keluarga. Masa kerja responden sebanyak 33,6\% selama lebih dari 20 tahun. Masa kerja yang relatif panjang menunjukkan individu sudah mampu mengelola interaksi pekerjaankeluarga sehingga menghasilkan outcome yang positif.

\section{Pengujian Model Pengukuran (Outer Model)}

Pengujian model pengukuran variabel laten untuk indikator refleksif dilakukan untuk melihat validitas masing-masing 
indikator dan menguji reliabilitas dari variabel laten. Menurut Ghozali (2008) dan Solimun (2011), kriteria validitas indikator dievaluasi dengan convergent dan discriminant validity, sementara reliabilitas variabel laten diukur dengan composite realibility.

Validitas konvergen dengan indikator refleksif dinilai berdasarkan korelasi antara item score/component score dengan construct score (Ghozali, 2008). Indikator dianggap valid jika memiliki nilai loading (original sample estimate) di atas 0,5 dan atau nilai $\mathrm{T}$ -
Statistic di atas 1,96 (Solimun, 2011: 119). Uji validitas konvergen dengan SmartPLS dapat dilihat dari results for outer loadings pada Tabel 1. Berdasarkan nilai outer loading atau T-statistik menunjukkan semua indikator pada variabel dukungan sosial profesional, dukungan sosial personal, pengayaan pekerjaan-keluarga, pengayaan keluarga-pekerjaan, kepuasan kerja dan kepuasan keluarga memenuhi kriteria validitas konvergen, artinya semua indikator pada variabel-variabel tersebut mampu mengukur variabel latennya.

Tabel 1

Result for Outer Loadings

\begin{tabular}{lcccc}
\hline \hline & $\begin{array}{c}\text { Original Sample } \\
\text { Estimate }\end{array}$ & $\begin{array}{c}\text { Mean of } \\
\text { Subsamples }\end{array}$ & $\begin{array}{c}\text { Standard } \\
\text { Deviation }\end{array}$ & T-Statistic \\
\hline Dukungan Sosial Profesional & & & \\
prof1 & 0,648 & 0,630 & 0,102 & 6,352 \\
prof2 & 0,764 & 0,760 & 0,050 & 15,324 \\
prof3 & 0,817 & 0,815 & 0,036 & 23,005 \\
prof4 & 0,760 & 0,761 & 0,080 & 9,482 \\
prof5 & 0,630 & 0,627 & 0,076 & 8,311 \\
\hline Dukungan & Sosial Personal & & & \\
\hline pers1 & 0,590 & 0,563 & 0,118 & 4,983 \\
pers2 & 0,810 & 0,796 & 0,059 & 13,645 \\
pers3 & 0,655 & 0,632 & 0,109 & 5,981 \\
pers4 & 0,792 & 0,793 & 0,049 & 16,331 \\
pers5 & 0,568 & 0,568 & 0,114 & 4,979 \\
\hline Pengayaan Pekerjaan-Keluarga & & & \\
\hline ppk1 & 0,906 & 0,903 & 0,021 & 42,212 \\
ppk2 & 0,904 & 0,906 & 0,023 & 39,198 \\
ppk3 & 0,848 & 0,836 & 0,049 & 17,403 \\
\hline Kepuasan Kerja & & & & \\
\hline puas1 & 0,815 & 0,810 & 0,050 & 16,416 \\
puas2 & 0,712 & 0,703 & 0,068 & 10,403 \\
puas3 & 0,723 & 0,730 & 0,059 & 12,197 \\
puas4 & 0,838 & 0,830 & 0,038 & 21,914 \\
puas5 & 0,704 & 0,686 & 0,086 & 8,217 \\
\hline Pengayaan Keluarga-Pekerjaan & & & \\
\hline pkp1 & 0,919 & 0,917 & 0,017 & 54,078 \\
pkp2 & 0,865 & 0,861 & 0,037 & 23,534 \\
pkp3 & 0,919 & 0,919 & 0,018 & 51,088 \\
\hline Kepuasan Keluarga & & & \\
\hline keluarga1 & 0,921 & 0,918 & 0,017 & 25,715 \\
keluarga2 & 0,896 & 0,889 & 0,035 & \\
\hline Sar & & & \\
\hline
\end{tabular}

Sumber: Data Primer Diolah 
Validitas diskriminan dengan indikator refleksif dinilai berdasarkan cross loading (Solimun, 2011). Jika korelasi konstruk dengan indikator pengukuran lebih besar daripada ukuran konstruk lainnya, maka konstruk laten memprediksi ukuran pada blok mereka lebih baik daripada ukuran pada blok lainnya (Ghozali, 2008).

Tabel 2

Cross Loading

\begin{tabular}{lcccccc}
\hline \hline & Profesional & Personal & PPK & Puas & PKP & Keluarga \\
\hline keluarga1 & 0,413 & 0,373 & 0,610 & 0,556 & 0,696 & 0,921 \\
keluarga2 & 0,528 & 0,376 & 0,575 & 0,522 & 0,696 & 0,896 \\
pers1 & 0,537 & 0,590 & 0,202 & 0,369 & 0,294 & 0,350 \\
pers2 & 0,281 & 0,810 & 0,370 & 0,414 & 0,378 & 0,434 \\
pers3 & 0,288 & 0,655 & 0,246 & 0,409 & 0,246 & 0,297 \\
pers4 & 0,279 & 0,792 & 0,320 & 0,370 & 0,396 & 0,337 \\
pers5 & 0,229 & 0,568 & 0,237 & 0,139 & 0,270 & 0,284 \\
pkp1 & 0,400 & 0,350 & 0,510 & 0,442 & 0,919 & 0,677 \\
pkp2 & 0,366 & 0,300 & 0,430 & 0,336 & 0,865 & 0,528 \\
pkp3 & 0,436 & 0,344 & 0,494 & 0,421 & 0,919 & 0,703 \\
ppk1 & 0,463 & 0,434 & 0,906 & 0,579 & 0,698 & 0,793 \\
ppk2 & 0,382 & 0,292 & 0,904 & 0,487 & 0,581 & 0,684 \\
ppk3 & 0,401 & 0,407 & 0,848 & 0,473 & 0,569 & 0,623 \\
prof1 & 0,648 & 0,374 & 0,325 & 0,465 & 0,516 & 0,422 \\
prof2 & 0,764 & 0,338 & 0,341 & 0,424 & 0,482 & 0,544 \\
prof3 & 0,817 & 0,406 & 0,429 & 0,703 & 0,582 & 0,562 \\
prof4 & 0,760 & 0,280 & 0,347 & 0,656 & 0,414 & 0,321 \\
prof5 & 0,630 & 0,350 & 0,404 & 0,405 & 0,407 & 0,563 \\
puas1 & 0,488 & 0,303 & 0,511 & 0,815 & 0,456 & 0,635 \\
puas2 & 0,515 & 0,420 & 0,370 & 0,712 & 0,411 & 0,366 \\
puas3 & 0,413 & 0,300 & 0,331 & 0,723 & 0,386 & 0,407 \\
puas4 & 0,480 & 0,379 & 0,430 & 0,838 & 0,419 & 0,558 \\
puas5 & 0,312 & 0,319 & 0,297 & 0,704 & 0,309 & 0,407 \\
\hline
\end{tabular}

Sumber: Data Primer Diolah

Berdasarkan hasil cross loading pada Tabel 2 menunjukkan bahwa semua indikator masing-masing variabel memprediksi variabel latennya sendiri lebih baik daripada indikator variabel laten yang lain, hal ini ditunjukkan oleh nilai korelasi konstruk dengan indikator pengukuran lebih besar daripada ukuran konstruk lainnya, artinya semua indikator masing-masing variabel telah memenuhi validitas diskriminan.

Metode lainnya untuk menguji validitas diskriminan adalah dengan membandingkan nilai akar AVE untuk setiap variabel laten dengan koefisien korelasi antar varibel laten (Solimun, 2011). Jika akar AVE lebih besar dari korelasi antara variabel laten tersebut dengan variabel laten lainnya, maka validitas diskriminan terpenuhi.

Berdasarkan Tabel 3 menunjukkan variabel laten dukungan sosial profesional, dukungan sosial personal, pengayaan pekerjaan-keluarga, pengayaan keluargapekerjaan, kepuasan kerja dan kepuasan hidup memiliki nilai akar AVE lebih besar dari pada korelasi antar variabel laten tersebut, sehingga semua variabel laten memenuhi validitas diskriminan. 
Tabel 3

AVE, Square Root AVE, and Correlations of the Latent Variables

\begin{tabular}{lcccccccc}
\hline \hline & AVE & $\begin{array}{c}\text { Root } \\
\text { Square } \\
\text { AVE }\end{array}$ & Profesional & Personal & PPK & Puas & PKP & Keluarga \\
\hline Profesional & 0,529 & 0,727 & 1,000 & & & & & \\
Personal & 0,476 & 0,690 & 0,425 & 1,000 & & & & \\
PPK & 0,785 & 0,886 & 0,531 & 0,529 & 1,000 & & & \\
Puas & 0,578 & 0,760 & 0,546 & 0,472 & 0,626 & 1,000 & & \\
PKP & 0,813 & 0,902 & 0,540 & 0,497 & 0,825 & 0,518 & 1,000 & \\
Keluarga & 0,825 & 0,908 & 0,485 & 0,434 & 0,793 & 0,539 & 0,762 & 1,000 \\
\hline
\end{tabular}

Sumber: Data Primer Diolah

Reliabilitas komposit digunakan untuk menguji kekonsistenan pengertian butirbutir instrumen penelitian menurut penilaian responden. Instrumen penelitian dikatakan reliabel jika nilai reliabilitas komposit di atas 0,7 (Solimun, 2011). Nilai reliabilitas komposit pada Tabel 4 menunjukkan masing-masing variabel laten telah memenuhi reliabilitas komposit yang baik.

Tabel 4

Composite Reliability

\begin{tabular}{lc}
\hline \hline & $\begin{array}{c}\text { Composite } \\
\text { Reliability }\end{array}$ \\
\hline Dukungan Sosial Profesional & 0,848 \\
Dukungan Sosial Personal & 0,817 \\
Pengayaan Pekerjaan-Keluarga & 0,916 \\
Kepuasan Kerja & 0,872 \\
Pengayaan Keluarga-Pekerjaan & 0,929 \\
Kepuasan Keluarga & 0,904 \\
\hline Sumber: Data Primer Diolah &
\end{tabular}

Pengujian Model Struktural (Inner Model)

Model struktural (inner model) dievaluasi dengan melihat goodness of fit melalui nilai R-square masing-masing variabel endogen dan Q-squarepredicitive relevance. Setelah memenuhi goodness of fit, selanjutnya dilakukan interpretasi terhadap koefisien jalurnya.

Nilai R-square digunakan untuk menilai pengaruh variabel laten independen terhadap variabel laten dependen apakah mempunyai pengaruh yang substantif (Ghozali, 2008). Tabel 5 menunjukkan nilai R-square variabel endogen.

Nilai R-square variabel pengayaan pekerjaan-keluarga sebesar 0,281, artinya variabilitas variabel pengayaan pekerjaan- keluarga dijelaskan oleh variabilitas variabel dukungan sosial profesional sebesar $28,1 \%$ sedangkan $71,9 \%$ dijelaskan oleh variabel lain di luar model. Nilai R-square variabel pengayaan keluarga-pekerjaan sebesar 0,247, artinya variabilitas variabel pengayaan keluarga-pekerjaan dijelaskan oleh variabilitas variabel dukungan sosial personal sebesar $24,7 \%$ sedangkan $75,3 \%$ dijelaskan oleh variabel lain di luar model. Nilai R-square variabel kepuasan kerja sebesar 0,392, artinya variabilitas variabel kepuasan kerja dijelaskan oleh variabilitas variabel pengayaan pekerjaan-keluarga dan pengayaan keluarga-pekerjaan sebesar $39,2 \%$ sedangkan 60,8\% dijelaskan oleh variabel lain di luar model. Nilai R-square 
variabel kepuasan keluarga sebesar 0,665, artinya variabilitas variabel kepuasan keluarga dijelaskan oleh variabilitas variabel pengayaan pekerjaan-keluarga dan pengayaan keluarga-pekerjaan sebesar $66,5 \%$ sedangkan 33,5\% dijelaskan oleh variabel lain di luar model.

Tabel 5

R-Square

\begin{tabular}{lc}
\hline \hline & R-Square \\
\hline Pengayaan Pekerjaan-Keluarga & 0,281 \\
Kepuasan Kerja & 0,392 \\
Pengayaan Keluarga -Pekerjaan & 0,247 \\
Kepuasan Keluarga & 0,665 \\
\hline Sumber: Data Primer Diolah &
\end{tabular}

Q-squarepredicitive relevance mengukur seberapa baik nilai observasi dihasilkan oleh model dan estimasi parameternya. Nilai Q-square lebih besar dari nol menunjukkan bahwa model mempunyai nilai predictive relevance. Rumus $\mathrm{Q}^{2}=1-\left(1-\mathrm{R}_{1}{ }^{2}\right)$ $\left(1-R_{2}^{2}\right)\left(1-R_{3}{ }^{2}\right)\left(1-R_{4}^{2}\right)$, sehingga besarnya nilai $\mathrm{Q}^{2}=1-(1-0,281)(1-0,392)(1-0,247)$ $(1-0,665)=0,890$. Nilai Q-square tersebut menunjukkan bahwa model sangat baik, yaitu mampu menjelaskan kepuasan kerja dan keluarga sebesar $89 \%$ sedangkan sisanya $11 \%$ dijelaskan oleh variabel lain di luar model.

Koefsien parameter jalur dapat dilihat dari result for inner weights. Untuk menilai signifikansi jalur struktural yang dihipotesiskan dapat dilihat dari nilai T-statistik yang lebih besar atau sama dengan 1,96. Hasil pengujian dapat dilihat pada Tabel 6.

Tabel 6

Results for Inner Weights

\begin{tabular}{lccc}
\hline \hline & Koefisien Jalur & T-Statistic & Keterangan \\
\hline $\begin{array}{l}\text { Dukungan Sosial Profesional ->Pengayaan } \\
\text { Pekerjaan-Keluarga }\end{array}$ & 0.531 & 8.340 & Signifikan \\
$\begin{array}{l}\text { Dukungan Sosial Personal ->Pengayaan } \\
\text { Keluarga-Pekerjaan }\end{array}$ & 0.497 & 6.655 & Signifikan \\
$\begin{array}{l}\text { Pengayaan Pekerjaan-Keluarga -> } \\
\text { Kepuasan Kerja }\end{array}$ & 0.622 & 4.206 & Signifikan \\
$\begin{array}{l}\text { Pengayaan Pekerjaan-Keluarga -> } \\
\text { Kepuasan Keluarga }\end{array}$ & 0.516 & 4.479 & Signifikan \\
$\begin{array}{l}\text { Pengayaan Keluarga-Pekerjaan -> } \\
\text { Kepuasan Kerja }\end{array}$ & 0.005 & 0.031 & $\begin{array}{c}\text { Tidak } \\
\text { Pengayaan Keluarga-Pekerjaan -> }\end{array}$ \\
$\begin{array}{l}\text { Kepuasan Keluarga } \\
\text { Sumber:Data Primer Diolah }\end{array}$ & 0.336 & 2.994 & $\begin{array}{l}\text { Signifikan } \\
\text { Surigan }\end{array}$ \\
\end{tabular}

Hasil estimasi koefisien parameter pengaruh antar variabel menunjukkan lima jalur yang signifikan dengan nilai koefisien positif yaitu pengaruh dukungan sosial profesional terhadap pengayaan pekerjaankeluarga, pengaruh dukungan sosial personal terhadap pengayaan keluarga pekerjaan, pengaruh pengayaan pekerjaankeluarga terhadap kepuasan kerja, pengaruh pengayaan pekerjaan-keluarga terhadap kepuasan keluarga dan pengaruh pengayaan keluarga-pekerjaan terhadap 
kepuasan keluarga. Dengan demikian hipotesis dalam model dapat diterima. Sementara jalur yang tidak signifikan adalah pengaruh pengayaan keluarga-pekerjaan terhadap kepuasan kerja. Gambar 3 menunjukkan model hasil penelitian setelah jalur yang tidak signifikan dikeluarkan yang didukung oleh data empirik.

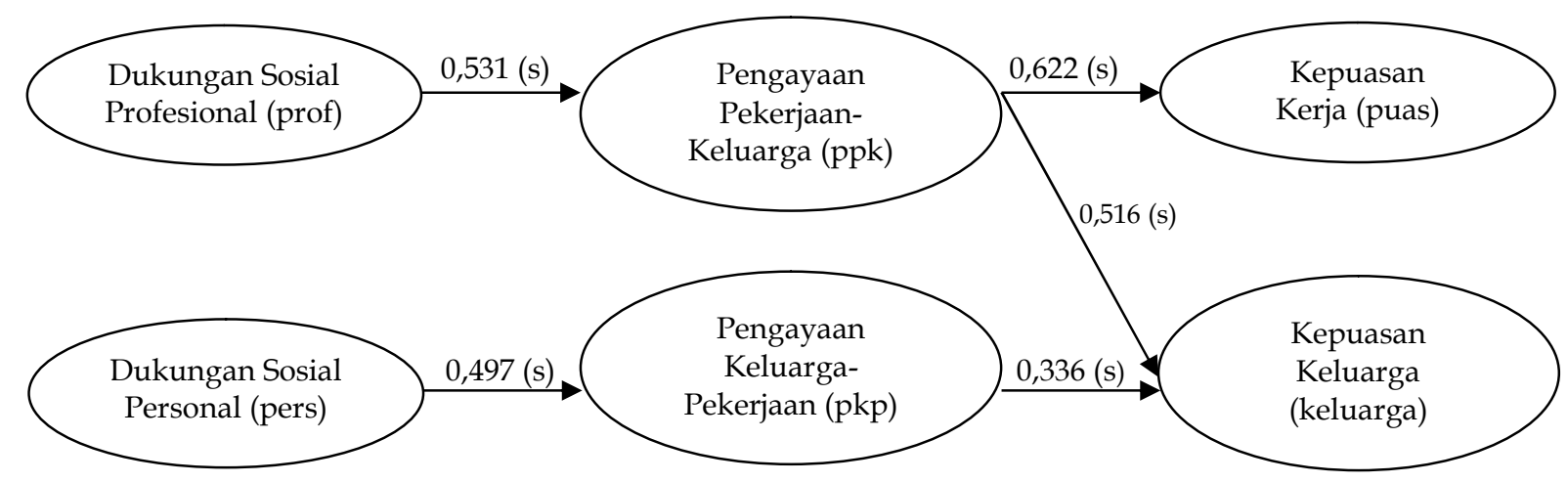

\section{Gambar 3 \\ Model Hasil Penelitian}

Sumber: Data Primer Diolah

\section{Pembahasan Hasil Penelitian}

Penelitian ini memfokuskan pada 1) peranan dukungan sosial profesional dan personal terhadap pengayaan pekerjaankeluarga dan keluarga pekerjaan; 2) pengaruh pengayaan pekerjaan-keluarga dan keluarga-pekerjaan terhadap kepuasan kerja dan kepuasan keluarga. Hasil penelitian membuktikan bahwa hanya satu hipotesis yang diajukan yang ditolak, yaitu pengaruh pengayaan keluarga-pekerjaan terhadap kepuasan kerja, sedangkan hipotesis lainnya dapat diterima.

Temuan penelitian mengindikasikan bahwa dukungan sosial profesional dan dukungan sosial personal berpengaruh positif dan signifikan terhadap pengayaan pekerjaan-keluarga dan pengayaan keluarga-pekerjaan. Hasil penelitian ini berhasil membuktikan model yang diajukan Powell dan Greenhaus (2006) dan Warner dan Hausdorf (2009) bahwa sumberdaya modal sosial (dukungan sosial profesional atau personal) dapat mempengaruhi kualitas kehidupan dalam peran lainnya (pekerjaan atau keluarga). Sumberdaya modal sosial dapat berupa materi, pengaruh dan informasi yang diperoleh dari relasi interpersonal dalam peran pekerjaan dan keluar- ga. Hasil penelitian ini juga mendukung penelitian Bhargava dan Baral (2009) yang menyimpulkan bahwa dukungan supervisor merupakan prediktor dari pengayaan pekerjaan-keluarga dan dukungan keluarga sebagai prediktor pengayaan keluargapekerjaan, penelitian Chu (2010) yang membuktikan dukungan keluarga berpengaruh terhadap pengayaan pekerjaan-keluarga. Selain itu, penelitian ini berkesesuaian dengan temuan penelitian Lu et al. (2009) yang menunjukkan bahwa dukungan sosial berhubungan dengan pengayaan pekerjaankeluarga.

Dukungan sosial dalam lingkungan kerja diperlukan setiap individu karena dukungan sosial yang diperoleh dari supervisor, rekan kerja, mentor dan pihak lain yang berhubungan dengan pekerjaan akan dapat mengurangi beban dan ketegangan yang dirasakan karyawan terhadap pekerjaannya (Bahrgava dan Baral, 2009). Dalam lingkungan kerja, dukungan dari supervisor, rekan kerja, mentor dan pihak lain yang berhubungan dengan pekerjaan merupakan sumber dukungan sosial. Supervisor diakui dapat memainkan peran penting dalam mengembangkan peran dan harapan karyawan, sehingga perilaku 
supervisor berdampak secara langsung terhadap reaksi afektif bawahannya (Boz et al., 2009). Rekan kerja memiliki peran yang sangat besar dalam memberikan dukungan sosial. Rekan kerja biasanya bersedia berbagi beban dan tanggung jawab kerja yang dirasakan berlebihan atau tidak dapat dijalani, memberikan bantuan materi maupun moril terhadap karyawan yang mengalami kesulitan. Demikian halnya dukungan sosial personal yang diperoleh dari orang tua, pasangan, anak-anak dan teman sangat diperlukan dalam meningkatkan interaksi positif pekerjaan-keluarga.

Menurut Wayne (2009) sumberdaya (termasuk sumberdaya modal sosial) merupakan kontributor utama hubungan positif antara pekerjaan-keluarga dan keluarga-pekerjaan. Sumberdaya dalam domain pekerjaan memprediksi pengayaan pekerjaan-keluarga, sementara sumberdaya dalam domain keluarga memprediksi pengayaan keluarga-pekerjaan. Dengan demikian, dukungan sosial profesional dan personal memungkinkan untuk meningkatkan interaksi positif pekerjaan dan keluarga.

Hasil penelitian menunjukkan bahwa pengayaan pekerjaan-keluarga berpengaruh positif dan signifikan terhadap kepuasan kerja dan kepuasan keluarga. Hasil penelitian ini mendukung kategori yang dibuat Allen et al. (2000) dan hasil meta analisis McNall et al. (2009) bahwa konsekuensi pengayaan pekerjaan-keluarga dapat berkaitan dengan pekerjaan (kepuasan kerja) dan bukan pekerjaan (kepuasan keluarga). Penelitian ini juga konsisten dengan model yang diajukan Wayne (2009) dan temuan penelitian yang dilakukan Carlson (2010), Hasan (2009) dan Schultz (2009) bahwa pengayaan pekerjaan-keluarga dapat meningkatkan kepuasan kerja.

Hasil penelitian menunjukkan bahwa pengayaan keluarga-pekerjaan berpengaruh positif signifikan terhadap keluarga tetapi tidak berpengaruh signifikan terhadap kepuasan kerja. Hasil penelitian mendukung kategorisasi yang dibuat Allen et al. (2000) yang menyatakan bahwa konsekuensi pengayaan keluarga-pekerjaan berkaitan dengan keluarga namun tidak konsisten dengan yang berkaitan dengan pekerjaan. Temuan ini juga mendukung penelitian Bhargava dan Baral (2009) dan Hasan et al. (2009) bahwa pengayaan keluarga-pekerjaan berhubungan positif dengan kepuasan kerja.

\section{SIMPULAN DAN SARAN Simpulan}

Berdasarkan hasil penelitian dan pembahasan yang telah diuraikan, maka dapat ditarik simpulan bahwa 1) dukungan sosial profesional berpengaruh positif signifikan terhadap pengayaan pekerjaan-keluarga; 2) dukungan sosial personal berpengaruh positif signifikan terhadap pengayaan keluarga-pekerjaan; 3) pengayaan pekerjaan-keluarga berpengaruh positif signifikan terhadap kepuasan kerja; 4) pengayaan pekerjaan-keluarga berpengaruh positif signifikan terhadap kepuasan keluarga; 5) pengayaan keluarga-pekerjaan berpengaruh positif tidak signifikan terhadap kepuasan kerja; 6) pengayaan keluarga-pekerjaan berpengaruh positif signifikan terhadap kepuasan keluarga.

\section{Saran}

Berdasarkan hasil penelitian, beberapa saran yang dapat disampaikan. Pertama, organisasi tidak hanya memfokuskan pada penanganan interaksi negatif pekerjaankeluarga (konflik pekerjaan-keluarga dan keluarga-pekerjaan) tetapi juga perlu mengembangkan strategi untuk meningkatkan interaksi positif pekerjaan-keluarga melalui pengembangan sumberdaya modal sosial maupun sumberdaya lainnya seperti keterampilan, sumberdaya psikologis dan fisik, fleksibilitas, sumberdaya material serta sumberdaya lainnya. Pengembangan sumberdaya tersebut dapat dilakukan melalui kebijakan tentang dukungan sosial atau program-program pelatihan yang dapat meningkatkan pengalaman dalam peran pekerjaan dan keluarga. Kedua, peneliti selanjutnya perlu mengembangkan 
penelitian dengan menginvestigasi sumberdaya-sumberdaya lainnya yang dapat dihasilkan dari peran pekerjaan dan keluarga sehingga dapat meningkatkan interaksi positif pekerjaan dan keluarga.

\section{Keterbatasan Penelitian}

Penelitian ini memiliki beberapa keterbatasan diantaranya, jumlah sampel yang relatif sedikit dan pengambilan data dilakukan dengan metode cross-section yang hanya mengobservasi fenomena pada satu titik sehingga tidak dapat menjelaskan perubahan dari populasi yang diamati dalam waktu berbeda.

\section{DAFTAR PUSTAKA}

Allen, T. D., D. E. L. Herst, C. S. Bruck, dan M. Sutton. 2000. Consequences Associated with Work-to-family Conflict: A review and Agenda for Future Research. Journal of Occupational Health Psychology 5: 278-308.

Bailyn, L., R. Drago, dan T. A. Kochan. 2001. Integrating Work and Family Life: A Holistic Approach. MIT Sloan School of Management. Massachusetts.

Bhargava, S. dan R. Baral. 2009. Antecedents and Consequences of Work-Family Enrichment among Indian Managers. Psychological Studies 54: 213-225.

Brummelhuis L. L. dan A. B. Bakker. 2012. A Resource Perspective on the WorkHome Interface: The Work-Home Resources Model. American Psychologist: 112.

Boz, M., I. Matrtinez, dan L. Munduate. 2009. Breaking Negative Consequences of Relationship Conflicts at Work: The Moderating Role of work Family Enrichment and Supervisor Support, The Colegio Oficial de Psicologos de Madrid 25(2): 113-120.

Carlson, D. S., J. G. Grzywacz, dan K. M. Kacmar. 2010. The Relationship of Schedule Flexibility and Outcomes Via the Work-Family Interface. Journal of Managerial Psychology 25(4): 330-355.
Carlson, D. S., M. K. Kacmar, J. H. Wayne, dan J. G. Grzywacs. 2006. Measuring the Positive Side of Work-Famiy Interface: Development and Validation of a Work-family Enrichment Scale. Journal of Vocational Behavior 68(1): 131164.

Chu, C. W. L. 2010. Development and Validation of A Multidimensional Scale of Work-Family Enrichment in A Chinese Context. Disertation. Aston University.

Crouter, A. C. 1984. Spillover from Family to Work: The Neglected Side of the Work-Family Interface. Human Relations 37(6): 425-41.

Edwards, J. R. dan N. P. Rothbard. 2000. Mechanisms Linking Work and Family: Clarifying the Relationship between Work and Family Construcs. Academy of Management Review 25: 178-199.

Ezzedeen, S. R. dan K. G. Ritchey. 2009. Career Advancement and Family Balance Strategies of Executive Women. Gender in Management: An International Journal 24(6): 388-411.

Frone, M. R. 2003. Work-Family Balance. Handbook of Occupational Health Psycho$\log y$. American Psychology Association. Washington DC.

Frone, M. R., M. Russell, dan M. L. Cooper. 1992. Antecedents and Outcomes Work-Family Conflict: Testing a Model of the Work-Family Interface. Journal of Applied Psychology 77(1): 65-78.

Ghozali, I. 2008. Structural Equation Modeling: Metode Alternatif dengan Partial Least Square. Edisi 2. Badan Penerbit Universitas Diponegoro. Semarang.

Gotlieb, B. H. 1983. Social Support Strategies: Guidelines for Mental Health Practice. Sage Publication Inc. California.

Greenhaus, J. H. dan N. J. Beutell. 1985. Sources of Conflict between Work and Family Roles. Academy of Management Review 10(1): 76-88.

Greenhaus, J. H. dan G. N. Powell. 2006. When Work and Family are Allies: A Theory of Work-Family Enrichment. 
Academy of Management Review 31(1): 72-92.

Grzywacz, J. G. dan N. F. Marks. 2000. Reconceptualizing the Work-Family Interface: An Ecological Perspective on the Correlates of Positive and Negative Spillover between Work and Family. Journal of Occupational Health Psychology 5: 111-126.

Haar, J.M. dan E.A. Bardoel. 2008. Possitive Spillover from the Work-Family Interface: A Study of Australian Employees. Asia Pasific Journal \& Human Resources 46(3): 276-287.

Hasan, Z., M. F. Dollard dan A. H. Winefield. 2009. Work-Family Enrichment: Sharing Malaysian' Experiences. Proceedings of the $8^{\text {th }}$ Industrial $\mathcal{E}$ Organisational Psychology Conference Sydney.

Lu, J. F., O.L. Siu, P. Spector, dan K. Shi. 2009. Antecedents and Outcomes of a Four-Fold Taxonomy of Work-Family Balance in Chinese Employed Parents. Journal of Occupational Health Psychology 14:182-192.

Luthans, F. 2005. Organizational Behavior. 10th ed. The McGraw-Hill Companies, Inc. Boston.

Marks, S. R. 1977. Multiple Role and Role Strain Some Notes on Human Energy Time and Commitment. American Sociological Review 2: 921-936.

McNall, L. A., A. D. Masuda dan J. M. Nicklin. 2010. Flexible Work Arrangements, Job Satisfaction, and Turnover Intentions: The Mediating Role of Work-to-Family Enrichment. The Journal of Psychology 144(1): 61-81.

McNall, L. A., J. M. Nicklin, dan A. D. Masuda. 2009. A Meta-Analytic Review of the Consequences Associated with Work-Family Enrichment. Journal of Business and Psychology 25(3): 381-396.

Mondy, R. W. 2008. Manajemen Sumber Daya Manusia. Edisi ke-10. Erlangga. Jakarta.

Mustafa, N., A. Ahmad dan J. Uli. 2012. The Impact of Work-family Factors in the
Relationships Between Organizational and Occupational Characteristics and Intention to Stay. Asian Journal of Business and Management Sciences 1(1): 109-128.

Namayandeh, H., S. N. Yacoob, dan R. Juhari. 2010. The Influences of Work Support and Family Support on WorkFamily Conflict (W-FC) Among Married Female Nurses in Shiraz Iran. Journal of American Science 6(12): 534540.

Powell, G. N. dan J. H. Greenhaus. 2006. Is the Opposite of Positive Negative? Untangling the Complex Relationship between Work-Family Enrichmnet and Conflict. Career Development International 11(7): 650-659.

Rashid, W. E. W., M. S. Nordin, A. Omar, dan I. Ismail. 2011. Social Support, Work-Family Enrichment and Life Satisfaction among Married Nurses in Health Service. International Journal of Social Science and Humanity 1(2): 150155.

Robbins, S.P. 2003. Organizational Behavior. $10^{\text {th }}$ ed. Prentice Hall. New Jersey.

Ryan, A. M., A. D. Kriska, B. J. West, dan J. M. Sacco. 2001. Anticipated Work/ Family Conflict and Family Member Views: Role in Police Recruiting. Policing: An International Journal of Police Strategies \& Management 24(2): 228-239.

Sarafino, E. P. 1990. Health Psychology: Biophysical Interactions. John Wiley \& Sons. Toronto.

Schermerhorn, J. R. 2002. Management. $7^{\text {th }}$ ed. John Wiley \& Sons. New York.

Schultz, Lisa A. 2009. Exploring the Relationship Between the Positive and Negative Sides of the Work-Family Interface: The Role of Enrichment in Buffering the Effects of Time, Strain, and Behavior-Based Conflict. Disertation. Purdue University. Indiana.

Sieber, S. D. 1974. Toward a Theory of Role Accumulations. American Sociological Review 39(4): 567-578. 
Solimun. 2011. Aplikasi Analisis Multivariat: SEM dan PLS. FMIPA Universitas Brawijaya. Malang.

Stoddard, M. dan S. R. Madsen. 2007. Toward an Understanding of the Link Between Work-Family Enrichment and Health. Academy of Human Resource Development conference of the Americas.

Warner, M. A. dan P. A. Hausdorf. 2009. The Positive Interaction of Work and Family Roles: Using Need Theory to Further Understand the Work-Family
Interface. Journal of Managerial Psychology 24(4): 372-285.

Wayne, J. H. 2009. Reducing Conceptual Confusion: Clarifying the "Positive" Side of Work and Family. Paper presented at the Annual Conference for the Society of Industrial/Organizational Psychologist New Orlean Los Angeles.

Zhang, H., X. Zhou, Y Wang, dan M. H. Cone. 2011. Work-to Family Enrichment and Voice Behavior in China: The Role of Modernity. Front. Bus. Res. China 5(2): 199-218 